The Chittagong Univ. J. B. Sci., Vol. 5(1 \&2):37-44, 2010.

\title{
STUDIES OF THE HELCONINAE (BRACONIDAE: HYMENOPTERA) OF COX'S BAZAR AND CHITTAGONG IN BANGLADESH
}

\author{
M. HABIBUR RAHMAN \\ Department of Zoology, University of Chittagong, Chittagong-4331, Bangladesh
}

\begin{abstract}
Two genera of Helconinae (Hymenoptera: Braconidae) have been described and illustrated from the districts of Cox's Bazar and Chittagong in Bangladesh and a key for the genera is given. The genera are: Helcon Nees and Eubazus Nees. The genera Helcon and Eubazus are new records to the fauna of Bangladesh.
\end{abstract}

Key words : Braconidae, Helconini, Bangladesh, New World, Old World.

\section{INTRODUCTION}

The subfamily Helconinae contains 40 genera worldwide (Goulet and Huber 1993). The Helconinae is comprised of four tribes, three of which occur in the New World. The fourth tribe, Brulleiini is found in the Old World (Wharton et al. 1997). Some of these tribes may be monophyletic whereas others, e.g. Diospilini, appear to be less defined. The tribes are: a) Tribe Helconini: The tribe Helconini is worldwide in distribution and contains about 12 genera, three of which are found in the New World. b) Tribe Diospilini: The tribe Diospilini is worldwide in distribution and contains about 13 genera, five of which are found in the New World (Wharton et al. 1997). c) Tribe Brachistini: The tribe Brachistini is cosmopolitan and contains about 11 genera, six of which are found in the New World (Wharton et al. 1997). Shenefelt (1970) catalogued the World species of these tribes (a-c). d) Tribe Brulleiini: This tribe is found in the New World. No previous studies were made for helconines of Bangladesh, although they are very common. So, the present work was undertaken to describe the helconines of Bangladesh along with the preparation of keys for the genera.

\section{MATERIALS AND METHODS}

Collections of the specimens of helconines were made from different areas of Cox's Bazar and Sitakundo, Chittagong of Bangladesh. A total of two genera were sorted out from the collections during 2004 to 2006. The insects were collected by a sweep net and Malaise Traps. The collected specimens were 
brought to the laboratory and were mounted dry with pins on cards. Stainless steel, continental size pins with and without head (No. 0.5,1,2,3 and 40) were used for all mounting methods. The specimens were identified on the basis of the external morphological features viewed under a binocular microscope [MEIJI EMZ (IX-10, SWF 20X, No.8667)]. The terminology used to describe the characteristic morphological features of Hymenoptera and Braconidae was followed according to Achterberg (1979a, 1979b, 1984, 1988a, 1988b, 1990 and 1993), Shaw and Huddleston (1991), Goulet and Huber (1993), and Wharton et al. (1997). The identification of the specimens up to generic level was confirmed by D. L. J. Quicke, Department of Biology, Imperial College of Science, Technology and Medicine, London, UK (personal communication). The females of helconines genera are described in this paper and the specimens are stored in the Department of Zoology, University of Chittagong, Bangladesh.

\section{RESULTS AND DISCUSSION}

\section{Distinguishing features of Helconinae}

Members of the Helconinae are identified by the following combination of characters (Figs. 2-25): hind wing with anal cross vein (a) present; fore wing with two anal cross veins (1a and $2 \mathrm{a}$ ); second submarginal cell of fore wing present and narrowed anteriorly. The tribe Helconini contains rather large, robust braconids.

As currently recognised, Helconinae is a moderately large subfamily containing over 400 described species worldwide (Achterberg 1984). So far as is known all are solitary parasitoids, although biological information is lacking for most of the species. The current concept of the subfamily restricts it to groups that are koinobiont endoparasitoids of beetle larvae, and excludes several formerly included genera that attack other host groups (Huddleston 1978). Nevertheless, Helconinae is still a heterogeneous assemblage and not well characterized by synapomorphies: like other groups based largely on plesiomorphic characteristics, it is unlikely to be strictly holophylectic (Achterberg 1984). No attempts have been made to use members of the Helconinae in classical biological control programs. Because they attack Cerambycidae, helconines may play a role in natural control of potential pests (Wharton et al. 1997). 
HELCONINAE (BRACONIDAE: HYMENOPTERA) OF COX'S BAZAR

Description of the genera

Helcon Nees 1814 (Figs. 2-15)

Helcon Nees von Esenbeck. 1814: 216; Shenefelt. 1970: 192-196. Type-species: Helcon tardator Nees, 1814 (designation by Lepeletier de St. Fargeau \& Audinet-Serville 1827).

Materials examined: Bangladesh, Cox's Bazar, 2 q Helcon sp., 14.VIII.2004; 22.XI.2005. Collected by Arju. Specimens deposited in the Department of Zoology, University of Chittagong.

\section{Diagnosis}

"Frons with medial lamella or triangular horn (Figs. 10, 11); forewing r more than half-length of 3SR1 (Fig. 2); vein 1-SR of fore wing distinct (Fig. 2); vein $2 \mathrm{~A}$ of fore wing distinct (Fig. 2) and usually unsclerotized (Figs. 2); propodeal spiracle situated medially (Fig. 4): outer apex of fore tibia with large and wide lamella (Fig. 6); hind femur partly rugose ventrally (Fig. 12); inner hind spur shorter or subequal to outer hind spur and narrower (Fig. 6, 12); femur without ventral tooth (Figs. 6, 12)".

Because of their large size, Helcon are usually kept when encountered and thus are present in most collections. Helcon are the parasites of wood boring coleopteran larvae, belonging to the family Cerambycidae, Buprestidae and Curculionidae (Marsh 1979).

\section{Distribution}

Worldwide in distribution. Holarctic and Neotropical, widespread in temperate and subtropical countries (Quicke 1987). Helcon sp. was collected from Cox's Bazar, Chittagong, Bangladesh. It is a new record from Bangladesh. 
RAHMAN

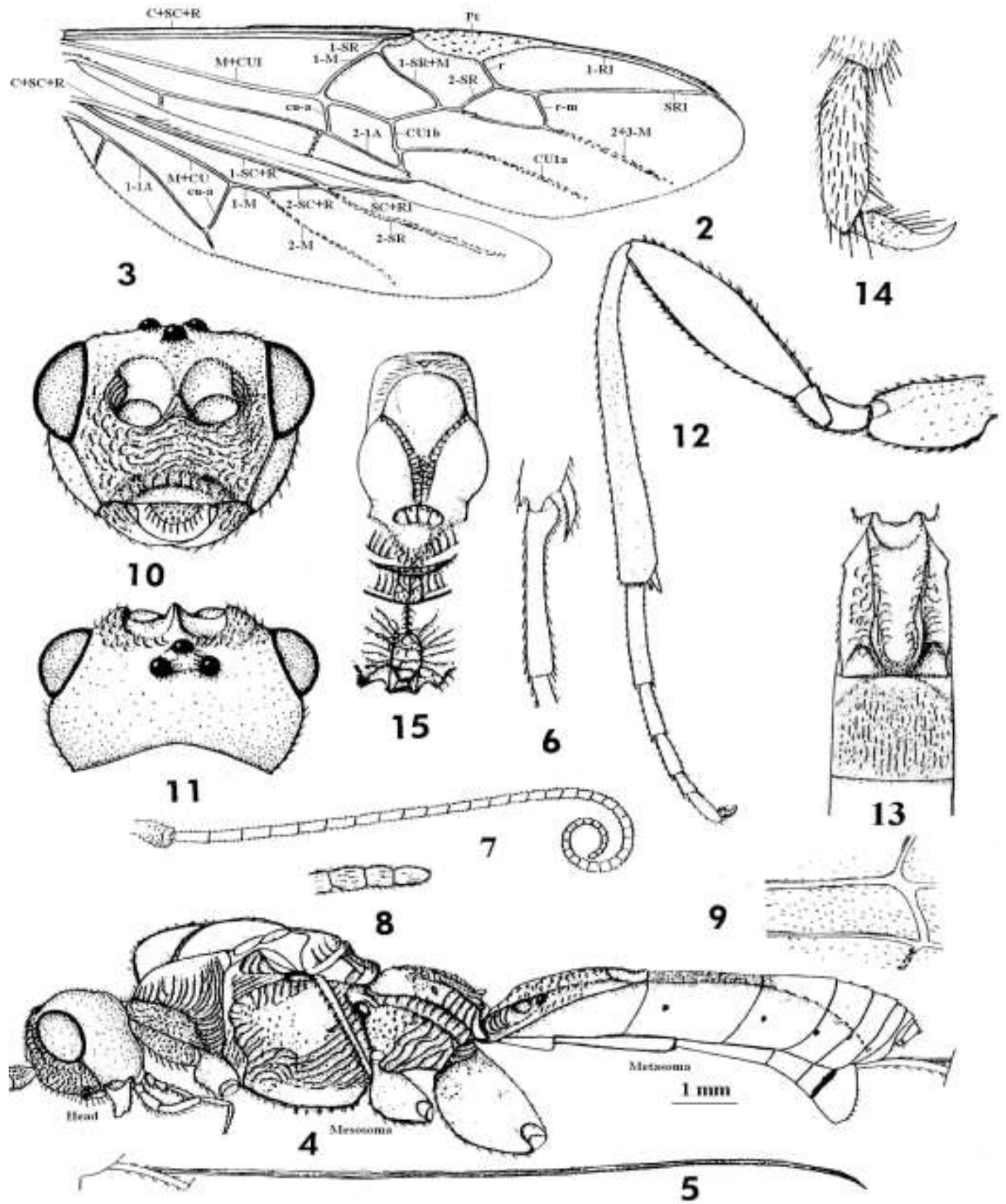

Figure 2-15. 


\section{HELCONINAE (BRACONIDAE: HYMENOPTERA) OF COX'S BAZAR}

FIGURE. 2 - 15 : HELCON SP., ․ FORE WING; 3, HIND WING; 4, HABITUS, LATERAL ASPECT; 5, OVIPOISITOR; 6, APEX OF FORE TIBIA AND SPUR; 7, ANTENNA; 8, APEX OF ANTENNA; 9, APICAL PART OF SUBBASAL CELL OF FORE WING; 9, HEAD, FRONTAL ASPECT; 11, HEAD, DORSAL ASPECT; 12, HIND LEG; 13, FIRST AND SECOND METASOMAL TERGITES; 14, OUTER HIND CLAW; 15, MESOSOMA, DORSAL ASPECT; PT, PTEROSTIGMA. MAGNIFICATION-2.5X IN FIG. 15; 3X IN FIGS. 2-7 AND 12-14; 3.5X IN FIGS. 10-11; AND 5X IN FIGS. 8-9. (WINGS ABBREVIATIONS: $\mathrm{A}=$ ANALIS; $\mathrm{C}=$ COSTA; $\mathrm{CU}=$ CUBITUS; $\mathrm{M}=$ MEDIA; $\mathrm{R}=$ RADIUS; $\mathrm{SC}=$ SUBCOSTA; $\mathrm{SR}=$ SECTO-RADII; SR1 $=1^{\text {ST }}$ ABSCISSA OF RADIUS; A = TRANSVERSE ANAL VEIN; CU-A = TRANSVERSE CUBITO-ANAL VEIN; M-CU = TRANSVERSE MEDIO-CUBITAL VEIN; $R$ $=$ TRANSVERSE RADIAL VEIN; R-M = TRANSVERSE RADIO-MEDIAL VEIN; 2R-M/2SR $=1^{\mathrm{ST}}$ TRANSVERSE RADIAL VEIN; PT = PTEROSTIGMA; 1R-M = NERVULUS $/$ BASELLA/ BASALIS; 1 -CU1 $=1^{\mathrm{ST}}$ ABSCISSA OF DISCOIDELLUS; 2 -CU1 $=2^{\mathrm{ND}}$ ABSCISSA OF DISCOIDELLUS; $3-\mathrm{CU} 1=3^{\mathrm{RD}}$ ABSCISSA OF DISCOIDELLUS; CU1A/ 3-CU $=$ APICAL ABSCISSA OF SUBDISCOIDELLUS).

\section{EUBAZUS NEES 1814 (Figs. 16-25)}

Materials examined: Bangladesh, Sitakundo, Chittagong, one $q$ Eubazus sp., 29.XII.2004; 22.XI.2005. Collected by: Sutapa. Specimens deposited in the Department of Zoology, University of Chittagong.

\section{Diagnosis}

"Vein r-m of fore wing absent (Fig. 16); 2cu-a of fore wing usually present (Fig. 16); occipital carina complete dorsally (Figs. 19, 20); petiole with basal, dorso-lateral pits (dorsope) weak (Fig. 24); scutellum without raised lateral margins (Fig. 18); subalar depression with transverse carina(e); metasomal terga 1 and 2 not fused (Fig. 24); metasoma variable, carapace like (Fig. 24); metasomal tergum 3 with lateral tergite separated from median tergite by sharp longitudinal fold (Figs. 18, 24)".

Eubazus are the parasites of Curculionidae and Bruchidae and perhaps other families of Coleoptera. No keys to New World species. Some importance in controlling weevil pests of wood (e.g. Pissodes) (Sharkey 1997).

\section{Distribution}

Cosmopolitan; several New World species, somewhat more diverse in the Neotropics (Wharton et al. 1997). Eubazus sp. was collected from Sitakundo, Chittagong, Bangladesh. It is a new record from Bangladesh.

Parasites of Curculionidae and Bruchidae and perhaps other families of Coleoptera. No keys to New World species. 
RAHMAN

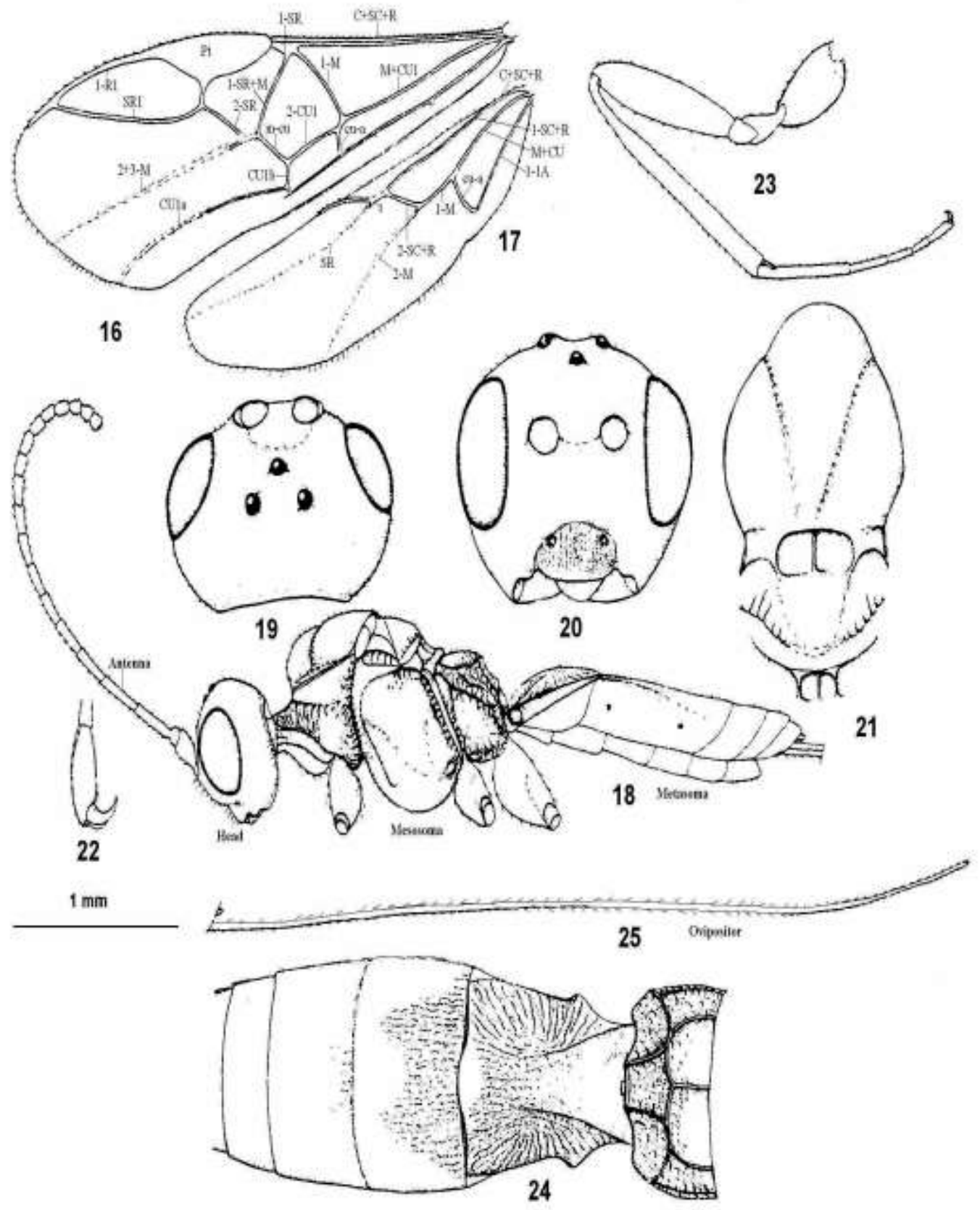

Figure 16-25. 


\section{HELCONINAE (BRACONIDAE: HYMENOPTERA) OF COX'S BAZAR}

FIGS. 16 - 25: EUBAZUS SP., +. 16, FORE WING; 17, HIND WING; 18, HABITUS LATERAL ASPECT; 19, HEAD, DORSAL ASPECT; 20, HEAD, FRONTAL ASPECT; 21, MESOSOMA, DORSAL ASPECT; 22, OUTER HIND CLAW; 23, HIND LEG; 24, FIRST - FOURTH METASOMAL TERGITES, DORSAL ASPECT; 25, OVIPOSITOR; PT, PTEROSTIGMA. MAGNIFICATION-1.5 IN FIGS. 22-25 AND 2X IN FIGS. 16-21. (WING ABBREVIATIONS ARE GIVEN IN PREVIOUS PAGES.)

Key to the genera of the subfamily Helconinae (Figs. 2-25)

1. Second submarginal cell of fore wing open, r-m absent (Figs. 16-17)... Eubazus Nees

- Second submarginal cell of fore wing-closed, r-m present (Fig. 2) ..........................2

2. Hind wing cross-vein a present (Figs. 1,3); second submarginal cell of fore wing narrowed anteriorly, 3SR1 shorter than 2M; fore wing $r$ more than half-length of 3RS1

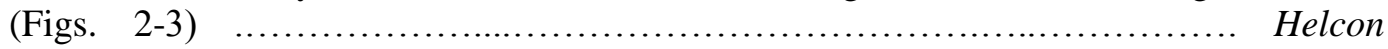
Nees

- Hind wing cross-vein a absent; second submarginal cell of fore wing widened anteriorly, 3SR1 longer than 2M; fore wing $\mathrm{r}$ less than half length of 3RS1 (belonging to. Diospilus Haliday (Not studied)

\section{ACKNOWLEDGEMENTS}

I wish to render grateful thanks to Dr. Donald Quicke, Imperial College of Science, Technology and Medicine, London for confirming the identifications. I would like to thank Professor Badrul Amin Bhuiya and Professor Dr. Ismail Miah, Department of Zoology, C.U. for their kind help in doing this work.

\section{REFERENCES}

ACHTERBERG, C. VAN. 1979a. A revision of the species of Amicrocentrinae, a new subfamily (Hymenoptera: Braconidae), with a description of the final larval instar of Amicrocentrum curvinervis by J.R.T. Short. Tijdschrift voor Entomologie 122: 1-28.

ACHTERBERG, C. VAN. 1979b. A revision of the subfamily Zelinae Auct. (Hymenoptera: Braconidae). Tijdschrift voor Entomologie 122: 241-479.

ACHTERBERG, C. VAN. 1984. Essay on the phylogeny of Braconidae (Hymenoptera: Ichneumonoidea). Entomologisk Tidskrift 105: 41-58.

ACHTERBERG, C. VAN. 1988a. Revision of the subfamily Blacinae Foerster (Hymenoptera: Braconidae). Zoologische Verhandelingen 249: 1-324.

ACHTERBERG, C. VAN. 1988b. Parallelisms in the Braconidae (Hymenoptera) with special reference to the biology. In Gupta V. K. (Ed.) Advances in parasitic Hymenoptera research: pp85-115. Leiden. 
ACHTERBERG, C. VAN. 1990. Illustrated key to the subfamilies of the Holarctic Braconidae (Hymenoptera: Ichneumonoidea). Zoologische Mededelingen 64: 1-20.

ACHTERBERG, C. VAN. 1993. Illustrated key to the subfamilies of the Braconidae (Hymenoptera: Ichneumonoidea). Zool. Verh. 283: 1-189.

GOULET, H. and HUBER, J. T. (Eds). 1993. Hymenoptera of the World: An Identification Guide to Families. Research Branch, Agriculture Canada, Ottawa. 668pp.

Huddleston, T. 1978. Braconidae [and] Aphidiidae. In Kloet, G. S. \& Hincks, W. D. A check list of British insects. (2nd edn) Part 4: Hymenoptera. Handbooks for the Identification of British Insects 11 (4): 46-62.

MARSH, P. M. 1979. Family Braconidae, Aphidiidae. In Krombein, K. V., Hurd, P. D., Smith, D. R. and Burks. B. D. (Eds.) Catalog of Hymenoptera in America north of Mexico 1: 144-313. Washington.

QUICKE, D. L. J. 1987. First host record for the genus Hyboteles van Achterberg (Hymenoptera: Braconidae). Proceedings and Transactions of the British Entomological and Natural History Society 20: 122.

SHARKEY, M. J. 1993. Family Braconidae. pp. 362-395. In Goulet H. \& Huber, J. T.(Eds), Hymenoptera of the World: An Identification Guide to Families. Agriculture Canada, Ottawa.

SHAW, M. R. AND HUDDLESTON, T. 1991. Classification and biology of braconid wasps (Hymenoptera: Braconidae). Handbooks for the Identification of British Insects 7(11): 1-126.

SHENEFELT, R. D. 1970. Braconidae 2. Helconinae, Calyptinae, Mimagathidinae, Triaspinae. Hymenopterorum Catalogus (nova editio) 5: 177-306.

WHARTON, R. A., MARSH, P. M. AND SHARKEY, M. J. 1997. Manual of the New world genera of the family Braconidae. Special Publication of The International Society of Hymenopterists, No. 1. 439pp.

Manuscript received on 18. 3. 2010; Accepted on 29.9.11

The Chittagong University Journal of Biological Sciences, Vol. 5 (1 \& 2). Page No:37-44 